\title{
The evolution of ecology in Mexico: facing challenges and preparing for the future
}

\author{
ML Martínez ${ }^{1 *}$, RH Manson ${ }^{1}$, P Balvanera ${ }^{2}$, R Dirzo ${ }^{3,4}$, J Soberón ${ }^{5}$, L García-Barrios ${ }^{6}$, M Martínez-Ramos ${ }^{2}$, \\ P Moreno-Casasola ${ }^{1}, \mathrm{~L}_{\text {Rosenzweig }}{ }^{7}$, and J Sarukhán ${ }^{3}$
}

We review and analyze the historical development and challenges facing ecology as a science in Mexico, a country with limited financial and human (one scientist per 5000 inhabitants) resources and numerous environmental problems. We outline a set of research, collaborative, and financial strategies that could help to strengthen the role of ecological science in decision-making processes, and increase cutting-edge research, thus helping to foster economic sustainability and human well-being in the country. Both curiosity driven and applied research will be important in this context. Interdisciplinary and inter-institutional approaches, as well as international collaborations, are also key elements in the continued development of ecology in Mexico. Ecological knowledge is predicted to play an increasingly important role in promoting the conservation and sustainable use of Mexico's natural resources and rich biodiversity. As the history and development of ecology in Mexico parallels other Latin American countries, some of our recommendations for the future of ecology in Mexico may apply elsewhere in Central and South America.

Front Ecol Environ 2006; 4(5): 259-267

A ccording to Aristotle, "If you would understand anything, observe its beginning and its development". Ecology is a relatively young science in Mexico and Latin

\section{In a nutshell:}

- Ecology as a scientific discipline in Mexico is less than six decades old and faces important challenges and limitations in human and financial resources

- Current strategies for facing such challenges include stimulating increased academic productivity while simultaneously promoting research with a social impact, and offering national graduate programs designed to increase the pool of ecologists over the long term; interdisciplinary, inter-institutional, and international collaborations are also important

- Promising directions for growth and consolidation include strengthening natural history and ecological theory, in conjunction with biodiversity science (magnitude, distribution, anthropogenic impacts), conserving the country's biodiversity, and providing ecosystem services in human-dominated landscapes

- Similarities between the evolution of ecology in Mexico and elsewhere in Latin America suggest that some of the current challenges and opportunities for ecological research may also be shared

${ }^{1}$ Departamento de Ecología Funcional, Instituto de Ecología, AC, $\mathrm{km}$ 2.5 ant Carretera a Coatepec no 351, Xalapa, Veracruz, 91070, México*(maluisam@ecologia.edu.mx); ${ }^{2}$ Centro de Investigaciones en Ecosistemas, UNAM, AP 27-3, Morelia Michoacán 58090 México; ${ }^{3}$ Instituto de Ecología, UNAM, AP 70-275, México 04510 DF; ${ }^{4}$ Current address: Department of Biological Sciences, Stanford University, Stanford CA 94305 USA; ${ }^{5}$ Current address: Biodiversity Research Center, Dyche Hall, University of Kansas, Laurence, KS 66045 USA; ${ }^{6}$ El Colegio de la Frontera Sur. Carretera Panamericana y Perisur (s/n). Barrio de María Auxiliadora. San Cristóbal de las Casas, Chiapas, México CP29290; ${ }^{7}$ Fondo Mexicano para la Conservación de la Naturaleza, AC, Damas 49, San José Insurgentes 03900, Mexico City, México
America as a whole. Understanding its evolution in this region depends in large part on analyzing the confluence of factors that have historically shaped this discipline. Combined with a review of current challenges, this should allow us to predict some future developments. Here, we briefly review the biophysical, socioeconomic, and scientific factors that have promoted the growth of ecology in Mexico and briefly explore how applicable these developments may be for Latin America as a whole. We use the case of Mexico to highlight some of the main difficulties facing ecologists working in developing countries with high biodiversity, but with limited budgets and numerous environmental problems (Sarukhán and Dirzo 2001). Finally, at a time when many professional societies with links to ecology are reflecting upon their main challenges as well as their visions for the future, we outline a set of strategies that could help to ensure that ecological science plays a substantial role in decision-making processes in Mexico. Although our analysis is focused on Mexico, we also discuss the above issues from a regional perspective where our experience and interactions with scientists from other Latin America countries suggest this would be useful.

\section{Historical trends}

The unique environment and evolutionary history of Latin America has played an important role in fostering an interest in the region's natural history and improving our ecological understanding. A long list of explorers and naturalists, including several founders of modern ecology such as Charles Darwin, Alfred R Wallace, and Alexander von Humboldt, were attracted to Latin America's enormous biotic and ecosystem-level diversity and productivity. These visitors and their studies served 


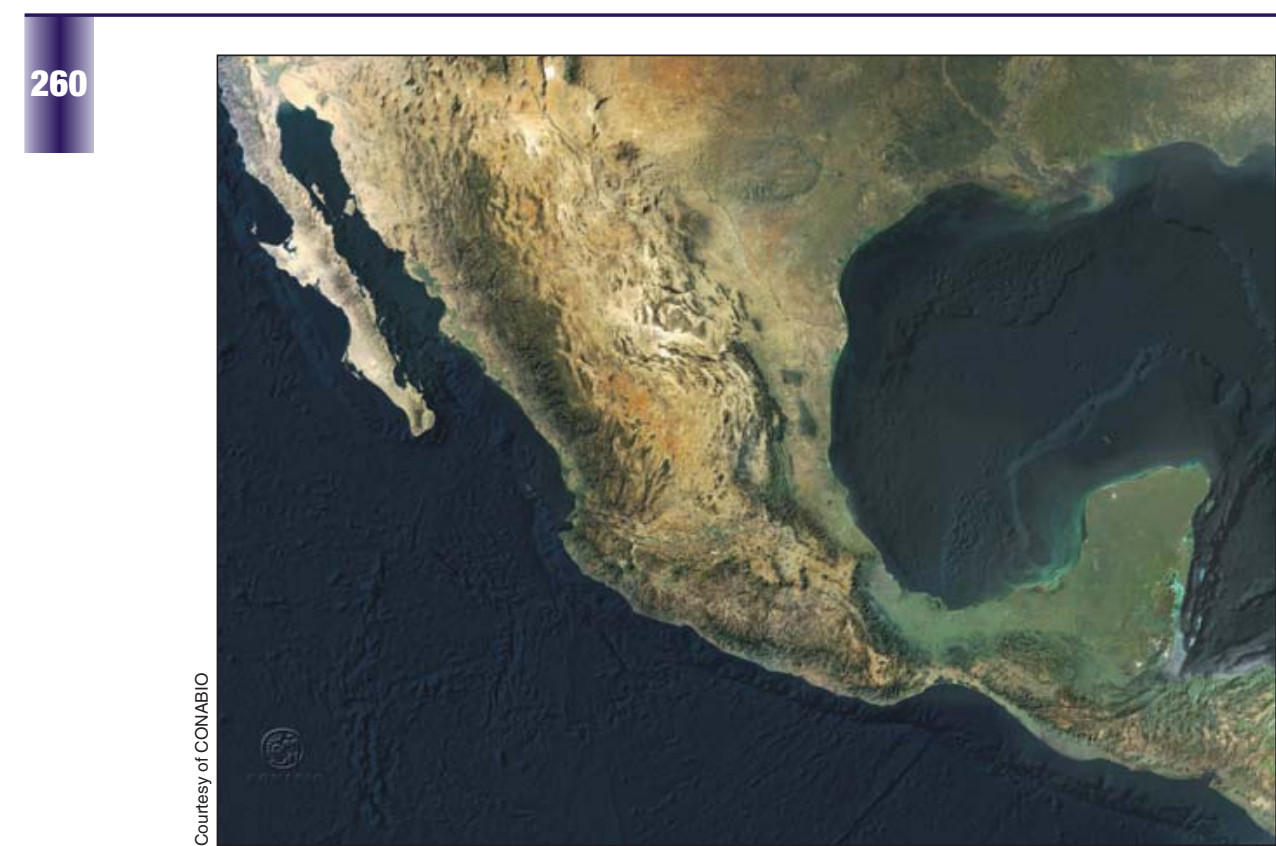

Figure 1. Mexico covers an area of $1972545 \mathrm{~km}^{2}$ and has $23761 \mathrm{~km}$ of coastline. It is a megadiverse country, with many endemic species: 140 mammals, 92 birds, and 12500 plants (Groombridge and Jenkins 2002).

to strengthen the union between natural history and natural philosophy, and encouraged the development of "scientific natural history" as a precursor to modern ecology, which combines analytical reasoning and exact measurements (Kingsland 2004).

As these early explorers noted, the region's biodiversity is remarkably high. Seven of the world's 25 most biologically rich terrestrial ecoregions are found in Latin America and the Caribbean, where more than 46000 vascular plants, 1597 amphibians, 1208 reptiles, 1267 birds, and 575 mammal species have been identified to date (UNEP 2002). In Mexico, a complex array of biogeographic (eg wide latitudinal range, highly variable topography) and evolutionary factors (eg glacial refuges, plate tectonics) have combined to create the fifth most biologically rich country in the world (Mittermeier et al. 1997; Figure 1). This pattern is repeated in numerous areas of South and Central America, which have been found to contain a disproportionate concentration of global biodiversity, including many endemic taxa (Myers et al. 2000; Dirzo 2001; Sarukhán and Dirzo 2001).

Tremendous cultural diversity has evolved in parallel with this biological diversity. Mexico is considered the birthplace of the major early civilizations of Mesoamerica and is currently home to 54 main indigenous groups, speaking 240 languages and dialects (nearly 60 of which are still spoken; Grimes 1988). In addition to languages and cultures, much of the indigenous knowledge of nature in Latin America, particularly in ethnobotany, ecology, and agroecosystem management, has been preserved (Denevan et al. 1984; Posey and Baleé 1989; Alcorn 1990; Gómez-Pompa et al. 1993; Toledo et al. 2003).

Despite this biological and cultural diversity, and the scientific interest it has generated in the past, the develop- ment of ecology as a formal discipline in Mexico, and elsewhere in Latin America, is a phenomenon of the 20th century (Castillo and Toledo 2000). This delay has its roots in Spanish colonialism, during which higher education (including science) in the New World was reserved for the elite (Cetto and Vessuri 1997), and whose policies of centralization and export-based economies tended to generate political and economic instability in the post-colonial era (Bulmer-Thomas 2003). Following the colonial period, Mexico was plunged into more than a century of dictatorships, monarchies, and civil war (Meyer et al. 2003), which damaged the country's socioeconomic infrastructure and resulted in widespread poverty. Today, close to $50 \%$ of Mexicans live on less than than US $\$ 2$ per day, and a quarter of the population live in extreme poverty (less than US $\$ 1$ per day; World Bank 2005). In addition, the United Nations reported that Mexico ranked in the lower quartile in the Wellbeing of Nations, a unique index combining indicators of human well-being (eg health, population, and wealth), with those of environmental sustainability (eg water quality, species diversity, and energy use; Prescott-Allen 2001). The country's population growth rate ( $2 \%$ over the past century, but currently $1.1 \%$ ), resulted in a seven-fold increase in population over the past 100 years (12.6 to 91.2 million from 1895-1995; INEGI 2005).

Combined with an uneven distribution of wealth, the globalization of markets, and a general lack of incentives for conservation, these increases have forced local inhabitants to pursue short-term exploitation strategies that have put considerable pressure on Mexico's natural resources. Environmental degradation has been exacerbated by uncertain land tenure, the collapse of traditional peasant institutions, perverse government subsidies (promoting large-scale deforestation), agricultural industrialization, and an acute lack of coordination between ministries (Stedman-Edwards 1998; Soberón et al. 1997). These and other factors were the root causes of many of Mexico's environmental problems, including high deforestation rates (about 700000 ha yr $^{-1}$; Masera et al. 1998), large-scale contamination of surface waters, depletion of aquifers, and serious soil erosion. In view of the fact that $60 \%$ of arable land and 70\% of Mexico's forests are under the control of 38000 small communities (Bray 1995), and that a substantial proportion of the remaining biodiversity exists in indigenous territories, there is an urgent need for applied research that considers the socioeconomic implications of different management alternatives. Policy interventions should aim to tackle environmental problems from this perspective (Castillo and Toledo 2000), as the need to encourage conservation by working with local people is increasingly apparent (Sarukhán and Dirzo 2001). 
The evolution of ecology as a discipline in Mexico began with interdisciplinary and applied collaborations between local scientists from related disciplines (agronomists, biologists, and geographers) and foreign ecologists (Castillo and Toledo 1999). Formalization of the discipline continued into the 1950s (Sarukhán 1981), as a result of collaborations between local scientists such as Enrique Beltrán and Isaac Ochotorena (biologists), Efraím Hernández Xolocotzi (agronomist), and Maximino Martínez (botanist), as well as refugees from the Spanish civil war, including Faustino Miranda (botanist), Federico Bonnet (entomologist), and Enrique Rioja (marine biologist). These scientists settled in Mexico and through the training of new students created important academic lineages.

Such collaborations were followed by the formal establishment of national ecological institutions and the training of new scientists, both at home and abroad (Sarukhán 1981; Jaksic and

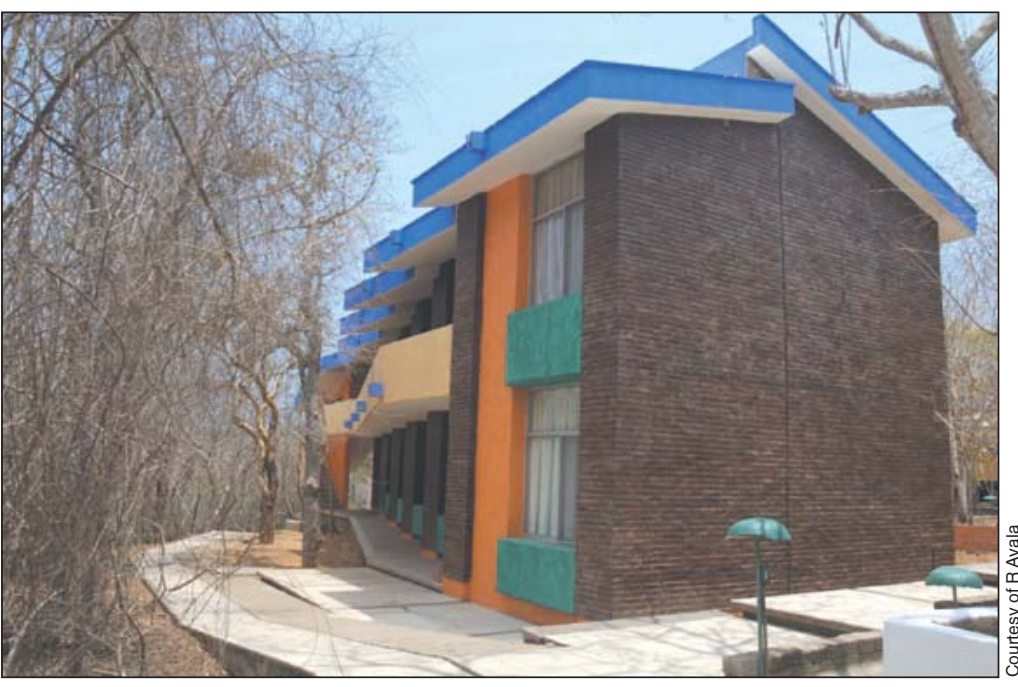

Figure 2. Biological research stations have been instrumental in the development of ecology in Mexico. Shown here are dormitories at the Estación de Biología Chamela, on the Pacific Coast of Mexico. Laboratories, scientific collections, and a library are also available on site.
Boyle 1992; Rabinovich and Boffi Lissin 1992; Castillo and Toledo 1999). Initially, the research was mostly descriptive, but with time there was increasing use of ecological paradigms, concepts, methods, and theory (Sarukhán 1981; Soberón 1995). During this time, the dominant focus in Mexico was on plant ecology (Dirzo 1993; Martínez-Ramos 1994).

Given the needs of the country, the first institutions established were interdisciplinary and focused on applied research. The National Commission for the Study of Dioscoreas was established in 1960, with support from the Forestry Ministry and a pharmaceutical industry that used yam (Dioscorea composita) to synthesize the first cortisone and all corticosteroids (including the birth-control pill) in Mexico. The Commission was charged with carrying out ecological studies on this plant and its natural habitat (tropical rainforest), including assessment of its availability and regenerative capacity in forests undergoing secondary succession. Such studies provided the first longterm, stable funding for population and community-level ecological research in Mexico (Sarukhán 1981). In addition, the Commission provided funding for training students in ecology, many of whom went on to play important roles in the growth of ecology in the country (Gómez-Pompa et al. 1967).

This establishment period was followed by a consolidation phase that included the birth and growth of a number of important ecological institutions and affiliated biological research stations. Three of these early institutions were established by academic descendents of the original founders of ecology in Mexico: the National Institute for the Investigation of Biotic Resources (A Gómez Pompa), The Institute of Ecology (G Halffter), and the Center of Ecology at the National University (J Sarukhán). Biological stations such as Los Tuxtlas, Chamela (Figure 2), Mapimí, El Edén, and El Cielo were (and still are) the sites where important ecological research was performed and where several generations of Mexican and Latin American scientists have been trained. Until 1978, the majority of new ecological knowledge was generated at research centers concentrated in Mexico City (Guevara and Moreno-Casasola 1981); however, this situation changed rapidly, and a variety of additional institutions, located throughout Mexico, now regularly contribute to the scientific output of the country. All of these research centers have regular budgets and a growing number of graduate programs (18 at present - more than any other country in Latin America; Castillo and Toledo 1999).

\section{- Challenges}

At present, limited federal funding is one of the major obstacles to the future development of ecology in Mexico and elsewhere in Latin America, where the percentage of GDP invested in research and development $(R \& D)$ ranges between 0.1 and 1.26 (Cetto and Vessuri 1997). In the case of Mexico, in 2003, R\&D spending accounted for only $0.42 \%$ of GDP (INEGI 2003). The national budget for research on environmental and natural resources is relatively small (US $\$ 43$ million dollars or $1.7 \%$ of the total R\&D budget in 2003; INEGI 2003). High quality ecology research centers, with the exception of the National Autonomous University of Mexico (eg ECOSUR - El Colegio de la Frontera Sur, and INECOL - Instituto de Ecología, AC), have yearly budgets ranging between US\$ 4-20 million per year (data obtained from institutional web pages).

In view of the scarce funding and the recent history of ecology, another important endeavor is to increase the small pool of trained scientists in Mexico. In 1980, the country had only five PhD-level scientists working in ecology (Soberón 1995). Currently, there are approximately 350 ecology researchers in Mexico (Castillo and 

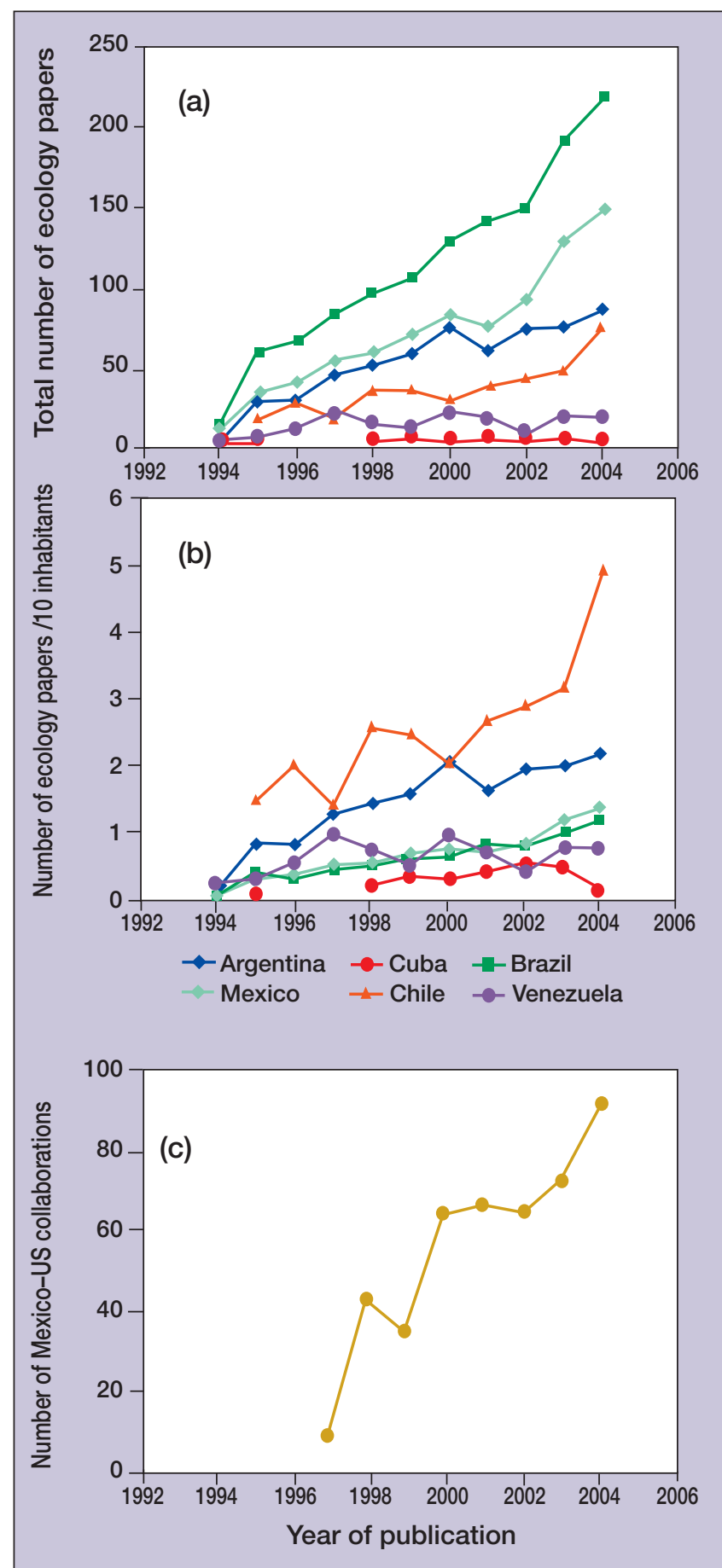

Figure 3. Number of articles found in Current Contents (ISI) by Mexican and Latin American authors that include the term "ecology" from 1997 to 2004. (a) Total number of papers from selected Latin American countries. (b) Per capita number of papers from selected Latin American countries. (c) Number of ecology papers including coauthors from both Mexico and the USA.

Toledo 2000), and an average of ten new PhDs are added each year (J Soberón pers comm). Although impressive, this growth is still insufficient, given the need for ecological research in the country. Regional trends for all sciences are similar; the number of researchers per capita in Latin America (one scientist per 5000 inhabitants) remains 10 times lower than in industrialized countries. An exception is Cuba, where the number of $R \& D$ research centers was increased to 221, employing more than 5000 researchers by 1998 (Cetto and Vessuri 1997). Most of these Cuban centers focus on biotechnology, agronomy, fisheries, and biomedicine. It has recently been estimated that in order to match the US capacity for training and employing scientists an initial investment of at least US $\$ 8$ billion would be required throughout Latin America (Rodríguez et al. 2005).

In response to these challenges, Mexican national policy has focused on increasing the quality and international impact of the limited amount of research being performed. The National Council for Science and Technology (Consejo Nacional de Ciencia y Tecnologia, CONACyT), through its National System of Investigators (Sistema Nacional de Investigadores, SNI), uses economic stimuli to encourage scientists to publish in international, peerreviewed, and indexed journals. CONACyT also encourages the maintenance of high-performance graduate programs by awarding scholarships to promising students. Similar internal programs have been created within many academic institutions nationally. While the net impact of these programs on academic production (both quantitatively and qualitatively) is still unclear, there has been a notable increase in the total number of ecology papers published annually by Mexican and Brazilian scientists (Figure 3a), despite negligible increases in the percentage of GDP invested in science during the same time period (Holmgren and Schnitzer 2004). When analyzed on a per capita basis, however, Chile and Argentina show the greatest increase in the number of ecology papers published during the past decade (Figure 3b). The overall contribution of the region to ecological knowledge worldwide is still rather limited, accounting for only $5.5 \%$ of total world production (ISI 2005).

There is growing recognition that investment in science is not a luxury but a necessity (Vessuri 2003). However, the low proportion of GDP actually invested in $\mathrm{R} \& \mathrm{D}$ in Mexico, and Latin America generally, suggests that policy makers consider that science does little to address their countries' environmental and socioeconomic problems. In Mexico, two trends are helping to address this situation. First, funding for applied, multidisciplinary work is increasing, in recognition of the fact that socially involved, ecological, "demand-driven research" (research aimed at solving specific problems) is just as relevant as "curiosity driven science" (research with no direct and immediate application). New "multiple-agency" funding alternatives are being created by CONACyT in collaboration with other federal and state institutions that not only increase overall funding available for research, but also promote the shift towards demand-based research (CONACyT 2003).

There is also a growing awareness of the importance of the link between ecosystem health and human well-being, expressed in the context of ecosystem services. Efforts to 
protect hydrological services in Mexico alone amounted to investments of over US\$43 million in 2003-2004 (CONAFOR 2005). This situation is representative of similar experiences in Latin America. In Costa Rica, for example, rural inhabitants are paid for the ecosystem services provided by their land, and this, coupled with a multi-sectoral approach and inter-administrational continuity, have converted high deforestation rates into substantial aforestation in recent years (Umaña and Brandon 1992). As efforts continue to understand and quantify the value of ecosystem services in Mexico and elsewhere in Latin America (SEMARNAP 1997; Pagiola et al. 2003), the demand for ecological studies will increase. Such changes should help to demonstrate the relevance of scientific research to society as a whole, and hopefully will result in a larger overall science budget in Latin America.

\section{Perspectives for the future}

Here, we will describe a set of strategies that should help ensure that this discipline remains vibrant, productive, and focused on resolving the major environmental problems facing the country. As starting points, we use the initiatives of several professional ecological organizations in Mexico and Latin America, including the Ecological Society of America (ESA) and the Association for Tropical Biology and Conservation (ATBC), currently engaged in defining their visions for ecology's future (Bawa et al. 2004; Palmer et al. 2005). Recommendations generated by these efforts were modified to reflect the realities and challenges of ecology as a science in Mexico. Some of these recommendations are likely to be applicable to other Latin American countries as well.

\section{Priority areas of research}

\section{Ecosystem structure and dynamics}

Understanding the biological and physical factors that generated and maintained the extremely high biodiversity in Latin American countries should be a fundamental focus of ecological research in the region. Cataloguing this biodiversity and elucidating the natural histories of species are also vitally important, but currently undervalued, scientific enterprises (Bawa et al. 2004). Research on the processes and mechanisms that determine ecosystem structure and functioning are also needed. These studies will serve as the baseline for understanding human impacts on natural ecosystems and developing appropriate restoration and management strategies.

\section{Anthropogenic effects}

In Mexico, undisturbed native vegetation covers less than a third of the country and the rate of deforestation is among the highest in Latin America (Masera et al. 1998; Palacio-Prieto et al. 2000; FAO 2003). Thus, an in-depth understanding of the ecological consequences of habitat loss, fragmentation, and different management practices on ecosystem structure and function is of the utmost importance. Paired with research identifying the ecological and socioeconomic drivers of land-use change (Geist and Lambin 2002) and global climate change (IPCC 2001), these studies will facilitate planning and forecasting future environmental scenarios and the prioritization of use, conservation, and restoration activities in different regions. Further work is also needed to determine what species live in environments that experience different management intensities, their life history traits, and what opportunities for biodiversity maintenance are offered by such environments.

\section{Ecological restoration}

Many of the effects of habitat loss and fragmentation are expressed cumulatively, over extended time periods (Dobson et al. 1997). Thus, a prompt response to environmental degradation, namely restoration of the most critical biotic communities, ecosystem functions, and the services they provide, is imperative (Costanza 1993; Daily 1997). However, additional ecological studies are needed to enhance our understanding of natural biotic regeneration processes and ecosystem function in order to develop strategies to accelerate ecosystem recovery and reduce the cost of restoration projects (Holl and Howarth 2000).

\section{Interdisciplinary research and sustainability}

Interdisciplinary research that incorporates socioeconomic, cultural, anthropological, and historic perspectives in solving complex environmental problems is urgently needed. Such research would help ensure that ecological knowledge is employed effectively in developing sustainable strategies for the use of natural resources in Mexico (Lubchenco et al. 1991; UN Millennium Project 2005).

\section{Agroecosystems}

Anthropogenic activities need not necessarily result in degraded ecosystems. Traditional ecological knowledge and indigenous agroecological management can be combined to create highly diverse agroecosystems that rival natural ones in ecosystem structure and function, while simultaneously meeting human needs (Gomez-Pompa et al. 1993; McNelly 1995; Mogeul and Toledo 1999; Toledo et al. 2003). Thus, new management approaches will result from exploring dynamic, complex interactions among humans and the ecosystems from which they receive ecosystem services.

This point is particularly relevant in Mexico, where national parks and biosphere reserves currently protect only $9 \%$ of the land area, while agroecosystems occupy a third of the country (Palacio-Prieto et al. 2000; Figure 4). Given this contrast, and the importance of communal 


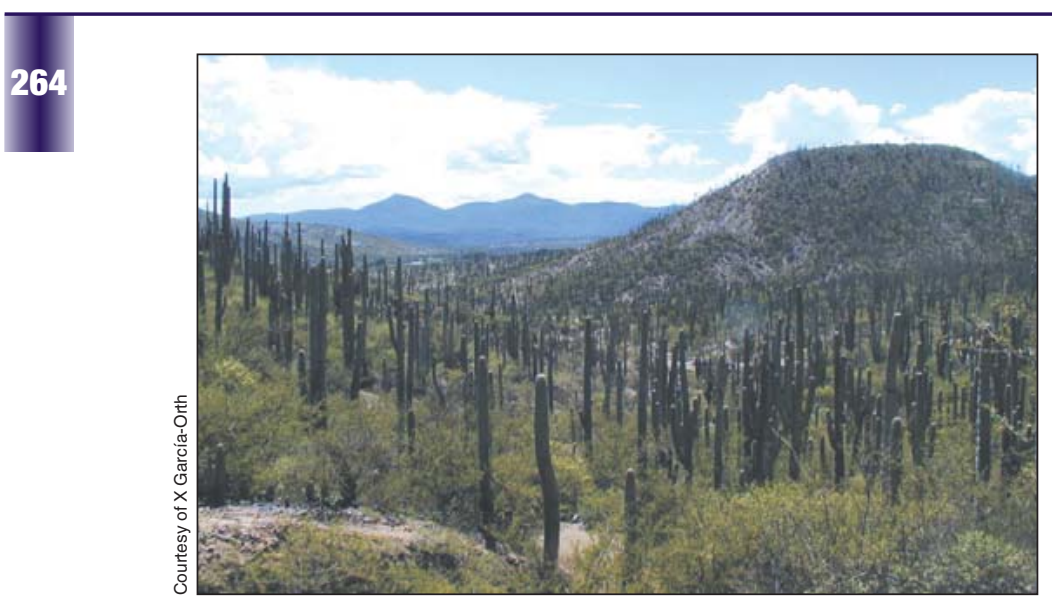

Figure 4. The Biosphere Reserve of the Tehuacán-Cuicatlan valley in the state of Oaxaca is a center of origin of a substantial number of species in the Family Cactaceae.

land ownership in Mexico (Castillo and Toledo 2000), more studies of these human-managed systems are needed, to combine traditional and modern ecological knowledge in the development of land-use strategies that maximize sustainability, landscape heterogeneity, and connectivity (Costanza 1993; Toledo et al. 2003). Directly related to this is the urgent need to generate scientific knowledge that minimizes the apparent conflicts between the conservation of biodiversity and the delivery of ecosystem services, underpinning societal well-being in human-dominated landscapes (Daily 2005).

\section{Ecosystem services}

The role of ecologists and ecology as a discipline will be key in: (1) ensuring the long-term sustainability and delivery of ecosystem services that are essential to national development; (2) understanding the consequences of different ecosystem management strategies on the ecosystem's health and its ability to deliver such services; (3) constructing a strong ecological knowledge base concerning the resistance and resilience of natural ecosystems to human perturbations; and (4) developing ecosystem management alternatives that maximize and balance the well-being of different sectors of society, while simultaneously strengthening the capacity of local, state, and country level institutions to develop, implement, and monitor ecosystem service payment programs (Castillo and Toledo 2000; UN Millennium Project 2005). In Mexico, it will be particularly important that such initiatives create alternatives for, directly involve, and economically compensate indigenous and peasant groups, who own a large proportion of the land. These groups often have a profound understanding of the ecosystems in their care, and are strongly influenced by governmental programs and market economies at a variety of scales.

\section{Monitoring networks}

These networks provide fundamental feedback for strengthening management and conservation programs, and for evaluating programs designed to preserve and restore ecosystem services. Monitoring networks are also essential for assessing climate change, and provide important opportunities for increasing environmental education and awareness. The recent establishment of a Long Term Ecological Research (LTER) network in Mexico is intended to support long-term research and the monitoring of key ecological, physical, and socioeconomic variables in various ecosystems throughout the country. Nine other countries in Latin America are also involved in, or are considering, similar initiatives (see www.ilternet.edu/networks/), suggesting that long-term monitoring is becoming an increasingly important tool used by ecologists in the region.

\section{Training priorities}

In Latin America, a growing proportion of ecology students are obtaining their Masters and $\mathrm{PhD}$ degrees within their home country, thanks to the recent proliferation of solid graduate programs and the difficulty of acquiring grants for studies abroad (Cetto and Vessuri 1997). Nevertheless, limited job opportunities continue to push young professionals abroad, creating a serious "braindrain" problem for Mexico and Latin America. It is estimated that $40-60 \%$ of Argentinean, Chilean, Colombian, and Peruvian researchers live and work outside their own countries (Cetto and Vessuri 1997). In Mexico, the number of federal grantees for graduate studies abroad in the past few decades far exceeds the number of members in the SNI, which has remained fairly constant over the same time period (CONACyT 2003). Efforts to develop local and regional science and technology should focus on retaining these highly valuable scientists, while continuing to foster international collaborations. Employment opportunities in Mexico and Latin America for young scientists are often very limited. Eliminating inconsistencies in governmental support, such as the inverse relationship between the number of investigators supported by the SNI in ecological institutions and the degree to which their research is applied to address national priorities in Mexico (Castillo and Toledo 2000), should also help to alleviate this problem. These criteria are changing slowly. Recent efforts to incorporate professionals trained as ecologists into federal and state agencies should create more opportunities for newly trained ecologists in Mexico.

New generations of ecologists also need training in how to engage in interdisciplinary research, particularly given the applied research agendas of Latin American countries (Palmer et al. 2005). In addition to a focus on problemsolving, communication skills for environmental education, and raising societal awareness, an interest in solving environmental problems and developing sustainable solutions is essential. Such environmental awareness is most effective if begun at an early age (K-12; Panel 1$)$. Efficient and constant communication between scientists and decision makers will ensure that this occurs. 
Panel 1. The "inquiry cycle" as a tool for ecological learning and conservation in Latin America

Hands-on scientific inquiry can provide local people with a powerful heuristic tool to better understand and eventually manage and conserve their surroundings. For over a decade the "inquiry cycle" has engaged Latin Americans in direct investigation of both basic and applied ecological processes. Latin Americans pose research questions themselves, design studies to answer them, and initiate wide-ranging reflection based on the results, a process which is often followed by direct applications to management or conservation. The inquiry cycle adapts itself to many different scales and social contexts, including professional and student ecologists, campesino and/or indigenous communities, forest guards in protected areas, and visitors to those areas or other "green places" (Feinsinger 2004; Feinsinger et al. 2006). The inquiry cycle especially pervades public education at sites across I5 Latin American nations, in the form of schoolyard ecology (la enseñanza de ecología en el patio de la escuela, "la EEPE"). Students in upper elementary grades and others from preschool to high school conduct scientifically rigorous inquiries into the plants, animals, ecological processes, and human "footprints" found in the schoolyard (Arango et al. 2005). Among its many results, schoolyard ecology greatly enhances knowledge of regional biodiversity and generates, without imposing, a culture of conservation.

\section{International collaboration}

Environmental problems are seldom neatly delineated within specific political, social, or economic boundaries. Solutions to these problems must therefore develop as a result of of international collaborations (Panel 2). The Latin American region already has several international programs for scientific collaboration, including the Latin American Plant Sciences Network (Red Latinoamericana de Bótanica, RLB), which was created in 1988 and supports graduate-level education in Mexico, Costa Rica, Venezuela, Brazil, Chile, and Argentina (Panel 3). Students from other Latin American countries are supported by RLB (www.uchile.cl/rlb) to carry out postgraduate studies or for short-term training. In addi- tion, the interaction between scientific societies (eg the Mexican and Latin American Botanical Societies) has resulted in fruitful collaborations in the region. Apart from these examples, links with scientists in developed countries are becoming more frequent, resulting in greater productivity (Figure 3c). All these types of partnerships serve to increase the overall funding available for ecological research in the region and, based on their success to date, should be strengthened and promoted in the future.

\section{Other financial opportunities}

A growing number of studies have documented the important economic returns for nations investing in science research and education (Vessuri 2003). In an ecological context, such investment provides the tools and depth of understanding needed to successfully deal with the many serious environmental problems facing Latin American countries. In Mexico, these problems were estimated to cost US $\$ 5.7$ billion in 2002, or almost $10 \%$ of GDP, whereas only $0.6 \%$ of GDP was spent on environmental protection during the same time period (value estimated using a June 2005 exchange rate; INEGI 2005). Until government investment in science increases in Latin America, alternative financial mechanisms should be explored, including partnerships with NGOs and the private sector. In addition to increasing support for science, such collaborations

\section{Panel 2. Environmental problems go beyond political frontiers}

As shown by the case of the monarch butterfly (Danaus plexippus), environmental problems often go beyond economic or political frontiers. This species is one of the best known of all North American butterflies due to its multi-generational migrations across the continent. In autumn, tens of millions of monarch butterflies leave their northern habitats in the northeastern USA and southern Canada and fly towards warmer areas of California and Mexico. Eventually, these individuals and their offspring will travel up to $4500 \mathrm{~km}$. Habitat destruction seriously threatens both the summer and overwintering sites of monarchs. By necessity, conservation of this species requires a trinational and multisectoral effort. Several programs and commissions have addressed the issue of protecting the monarch butterfly and the diverse array of habitats they use. The North American Commission for Environmental Cooperation (CEC) between Canada, Mexico, and the United States organized an international meeting to discuss the basic requisites to preserve the monarch butterfly. As a result, the core reserve in Michoacán (Mexico) was increased from 16110 to 56259 ha. Additionally, the Foundation for the Conservation of the Monarch Butterfly was created to compensate communities affected by this decision, as they can no longer benefit from logging activities within the reserve. Furthermore, work is being done with local agencies and citizens within the three countries to establish land protection and increase education about monarch conservation. Garden plantations of milkweed (the butterfly's food) are

being established and intense education programs are underway. Other programs aimed at the preservation of this butterfly are Michoacan Reforestation and Habitat Protection Fund, Monarch Butterfly Sanctuary Foundation, and Monarch Watch. In this, as in many other cases, international collaboration is fundamental to program success. 


\section{Panel 3. Scientific societies in Latin America fostering interactions among ecologists in the region}

At least eleven professional botanical, zoological, biological, and ecological societies and associations based in Latin America foster interactions between local ecologists and colleagues from related disciplines (see below). The Red Latinoamericana de Botánica (www.uchile.cl/rlb/) plays an important role in promoting student and teacher exchanges among countries in the region. Latin American ecologists also belong to international societies such as the Ecological Society of America, Association for Tropical Biology and Conservation, Society for Conservation Biology, British Ecological Society, and Society for Ecological Restoration. In addition, Latin American societies produce II journals with national/regiona distribution. However, only five of these (Revista Chilena de Historia Natural, Acta Zoológica Mexicana,Acta Botánica Mexicana, and Revista Mexicana de la Biodiversidad) are internationally indexed. Papers by Latin American ecologists can also be found in regional science journals, such as Interciencia, and the journals of the aforementioned societies and other professional organizations. In September 2005, the Mexican Society of Ecology was founded. Currently, it has nearly 200 members.

Largest scientific societies including ecologists based in Latin America.

\begin{tabular}{|c|c|c|c|}
\hline Organization & $\begin{array}{c}\text { Year } \\
\text { founded }\end{array}$ & $\begin{array}{l}\text { Members/meeting } \\
\text { attendance }\end{array}$ & Web page \\
\hline Sociedad Biológica de Chile & 1928 & $500 /$ na & www.biologiachile.cl/ \\
\hline Sociedad Botánica de México & 1941 & $1200 / 2000$ & www.socbot.org.mx/ \\
\hline Sociedade Botânica do Brasil & 1950 & na/na & www.botanica.org.br/ \\
\hline $\begin{array}{l}\text { Asociación Latinoamericana } \\
\text { de Botánica }\end{array}$ & 1986 & na $/ 1250$ & www.botanica-alb.org/ \\
\hline $\begin{array}{l}\text { Sociedad Mesoamericana para } \\
\text { la Biología y la Conservación } \\
\text { na = data not available }\end{array}$ & 1996 & 768 /na & www.socmesoamericana.org/ev.php \\
\hline
\end{tabular}

may have the added benefit of stimulating a more direct application of the scientific results to specific environmental problems, as well as facilitating the communication of these results to the general public.

\section{Conclusions}

A review of the evolution of ecology in Mexico reveals a surprising number of similarities with other Latin America countries, in terms of both historical development and the current challenges facing this discipline. We outline a strategy for addressing these problems, in the hope of maximizing research impacts in the short term and expanding the financial and human resources available for ecological research in the long term. Essential elements of this strategy include supporting curiosity driven research, while highlighting applied, interdisciplinary, and "demand-driven" ecological studies, as well as focusing research efforts on key topics, reducing "brain-drain", and strengthening national and international collaborations. This suite of actions should help to ensure that the quality and impact of ecological research in Latin America continues to improve, and that ecological knowledge plays a key role in promoting the conservation and sustainable use of the regions natural resources.

\section{Acknowledgements}

This paper is the integration of the talks presented at the symposium titled: "The evolution of ecology in Mexico: research challenges and the role of Mexico-US collaboration", sponsored by the Mexico Chapter and held at the 89th Annual Meeting of the Ecological Society of America, Portland, OR, USA, August 2004. We are very grateful to D Ackerly, N Anten, J Vandermeer, B Warner, I Mendelssohn, E Ezcurra, A Barahona, and G Halffter for their input during the symposium. The Instituto de Ecología, AC provided partial funding for this symposium.
P Feinsinger and G Carreño are thankfully acknowledged for their input for Panel 1.

\section{References}

Alcorn J. 1990. Indigenous agroforestry systems in the Latin American Tropics. In: Altieri M and Hecht S (Eds). Agroecology and small farm development. Boca Raton, FL: CRC Press.

Arango N, Chaves ME, and Feinsinger P. 2005. Schoolyard ecology: a conceptual and methodological guide. New York, NY: National Audubon Society.

Bawa KS, Kress WJ, Nadkami NM, and Lele S. 2004. Beyond paradise - meeting the challenges in tropical biology in the 21st century. Biotropica 36: 437-46.

Beltrán E. 1959. Los recursos naturales del sureste y su aprovechamiento. México, DF: Ediciones del IMERNAR.

Bray D. 1995. Peasant organizations and the permanent reconstruction of nature. J Environ Dev 4: 185-204.

Bulmer-Thomas V. 2003. The economic history of Latin America since independence. Cambridge Latin American Studies Series Number 77, Second Edition. Cambridge, UK: Cambridge University Press.

Castillo A and Toledo VM. 1999. La ecología en Latinoamérica: siete tesis para una ciencia pertinente en una región en crisis. Interciencia 24: 157-68.

Castillo A and Toledo VM. 2000. Applying ecology in the Third World: the case of Mexico. BioScience 50: 66-76

Cetto AM and Vessuri H. 1997. Science in Latin America. In: Krige J and Pestre D (Eds). Science in the 20th century. Paris, France: Harwood Academic Publishers.

CONACyT (Consejo Nacional de Ciencia y Tecnología). 2003. Informe general del estado de la ciencia y la tecnología: México 2003. México, DF: Consejo Nacional de Ciencia y Tecnología.

CONAFOR (Comisión Nacional Forestal) 2005. www.conafor.gob.mx/programas_nacionales_forestales/psa/index. html. Viewed 30 March 2006.

Costanza R 1993. Developing ecological research that is relevant for achieving sustainability. Ecol Appl 3: 579-81.

Daily GC. 1997. Introduction. What are ecosystem services? In: Daily GC (Ed). Nature's services: societal dependence on natural ecosystems. Washington, DC: Island Press.

Daily GC. 2005. Why biodiversity matters? In: Babbit B and Sarukhán J (Eds). Conserving biodiversity. Washington, DC: The Aspen Institute. 
Denevan WM, Treacy JM, Alcorn JB, et al. 1984. Indigenous agroforestry in the Peruvian Amazon: Bora Indian management of swidden fallows. Interciencia 9: 346-57.

Dirzo R. 1993. La ecología vegetal en México: logros y perspectivas. In: Guevara S, Moreno-Casasola P and Rzedowski J (Eds). Logros y perspectivas del conocimiento de los recursos vegetales de México en vísperas del Siglo XXI. México: Instituto de Ecologia AC.

Dirzo R 2001. Ecosystems of Central America. In: Levin SA (Ed). Encyclopedia of biodiversity. San Diego, CA: Academic Press.

Dobson AP, Bradshaw AD, Baker AJM. 1997. Hopes for the future: restoration ecology and conservation biology. Science 277: $515-22$.

FAO (Food and Agriculture Organization). 2003. The state of the world's forests 2003. Rome, Italy: United Nations Food and Agriculture Organization.

Feinsinger P. 2004. Diseño de estudios de campo para la conservación de la biodiversidad. Santa Cruz de la Sierra, Bolivia: Editorial FAN.

Feinsinger P, Alvarez S, Carreño G, et al. 2006. The key word is "local": place-based research by local people as a powerful tool in Latin American conservation. In: Billick IA and Price MV (Eds). The ecology of place: contributions of place-based research to ecological understanding. Chicago, IL: University of Chicago Press.

Geist HJ and Lambin EF. 2002. Proximate causes and underlying driving forces of tropical deforestation. BioScience 52: 143-50.

Gómez-Pompa A. 1967. Some problems in tropical plant ecology. J Arnold Arboretum 48: 195-221.

Gómez-Pompa A, Kaus A, Jiménez-Osornio J, et al. 1993. Mexico. In: NRC (Eds). Sustainable agriculture and the environment in the humid tropics. Washington, DC: National Academy Press.

Grimes B. 1988. Ethnologue: languages of the world. Dallas, TX: Summer Institute of Linguistics.

Guevara S and Moreno-Casasola P. 1981. Los congresos Mexicanos de botánica de 1960-1978. Bol Soc Bot Mex 40: 45-72.

Holmgren M and Schnitzer SA. 2004. Science on the rise in developing countries. PLoS Biology 2: 10-13.

Holl KD and Howarth RB. 2000. Paying for restoration. Rest Ecol 8: 260-67.

INEGI (Instituto Nacional de Estadística, Geografía e Informática). 2003. Sistema de cuentas económicas y ecológicas de México (SCEEM) 1997-2002. Mexico City, Mexico: Instituto Nacional de Estadística, Geografía e Informatica.

INEGI (Instituto Nacional de Estadística, Geografía e Informática). 2005. Historical statistics on-line. www.inegi.gob.mx Viewed 21 April 2005.

IPCC (Intergovernmental Panel on Climate Change). 2001. Scientific assessment of climate change. In: IPCC (Ed). Report of Working Group I. Cambridge, UK: University Press.

ISI. 2005. ISI Web of Knowledge, Web of Science. Thompson.

Jasik F and Boyle TP. 1992. The status of ecology in Chile. B Ecol Soc Am 73: 191-93.

Kingsland S. 2004. Conveying the intellectual challenge of ecology: a historical perspective. Front Ecol Environ 2: 367-74.

Lubchenco J, Olson AM, Brubaker LB, et al. 1991. The sustainable biosphere initiative: an ecological research agenda: a report from the Ecological Society of America. Ecology 72: 371-412

Martínez-Ramos M. 1994. Estudios y perspectivas sobre ecología vegetal en México. Bol Soc Bot Mex 55: 75-91.

Mittermeier RA, Robles-Gil P, and Mittermeier CG. 1997. Megadiversidad: los paises biológicamente más ricos del mundo. Mexico City, Mexico: Cementos Mexicanos.

Meyer M, Sherman WL, and Deed SM. 2003. The course of Mexican history, 7th edn. New York, NY: Oxford University Press.
Masera O, Ordoñez MJ, and Dirzo R. 1997. Carbon emissions from Mexican forests: current situation and long-term scenarios. Climatic Change 35: 265-95.

Myers N, Mittermeier RA, Mittermeier C, et al. 2000. Biodiversity hotspots for conservation priorities. Nature 403: 853-58.

Pagiola S, Bishop J, and Landell-Mills N. 2003. Selling forest environmental services. Market-based mechanisms for conservation and development. Washington, DC: Earthscan Publications Ltd.

Palacio-Prieto JL, Bocco G, and Velásquez A. 2000. Technical note: current situation of forest resources in Mexico: results of the 2000 National Forest Inventory, Investigaciones Geográficas. Boletín del Instituto de Geografía 43: 183-203.

Palmer MA, Bernhardt ES, Chornesky EA, et al. 2005. Ecological science and sustainability for the 21st century. Front Ecol Environ 3: 4-11.

Perfecto I, Mas A, Dietsch T, and Vandemeer J. 2003. Conservation of biodiversity in coffee agroecosystems: a tri-taxa comparison in southern Mexico. Biodivers Conserv 12: 1239-52

Posey DA and Baleé W (Eds). 1989. Resource management in Amazonia: indigenous folk strategies. Adv Econ Bot 7: 1-287.

Prescott-Allen R. 2001. The wellbeing of nations: a country-bycountry index of quality of life and the environment. Covelo, CA: IDRC/Island Press.

Rabinovich J and Bofia Lissin LD. 1992. La ecología en la República Argentina. Ecología Austral 2: 109-22.

Rodríguez JP, Simonetti JA, Premoli A, and Marini MA. 2005. Conservation in Austral and Neotropical America: building scientific capacity equal to the challenges. Conserv Biol 19: 969-72.

Sarukhán J. 1981. In: Kormondy EJ and McCormick F (Eds). Handbook of contemporary developments in world ecology. Westport, CT: Greenwood Press.

Sarukhán J and Dirzo R. 2001 Biodiversity rich countries. In: Levin SA (Ed). Encyclopedia of biodiversity. San Diego, CA: Academic Press.

SEMARNAP (Secretaria del Medio Ambiente, Recursos Naturales y Pesca). 1997. Economía ambiental: lecciones de América Latina. Mexico City, Mexico: Secretaria del Medio Ambiente, Recursos Naturales y Pesca.

Soberón JM. 1995. Algunas ideas sobre el desarrollo y las perspectivas de la ecología en México. Ciencia 46: 5-8.

Soberón J, Quadri G, and Villalón F. 1997. Land tenure and natural protected areas: the case of Mexico. In: Organization for Economic Co-Operation and Development (Ed). Investing in biological diversity. Proceedings of the OECD International Conference on Incentive Measures for the Conservation and Sustainable Use of Biological Diversity. Cairns, Australia

Stedman-Edwards 1998. Root causes of biodiversity loss: an analytical approach. Washington, DC: World Wildlife Fund.

Toledo VM, Ortiz-Espejel B, Cortés L, et al. 2003. The multiple use of tropical forests by indigenous peoples in Mexico: a case of adaptive management. Conserv Ecol 7: 9. www.consecol.org/vol7/iss3/art9. Viewed 30 March 2006.

Umaña A and Brandon K. 1992. Inventing institutions for conservation: lessons from Costa Rica. In: Sheldon A (Ed). Poverty, natural resources and public policy in Central America. New Brunswick, NJ: Transaction Books.

UN Millenium Project. 2005. Environment and human well-being: a practical strategy. Report of the Task Force on Enviromental Sustainability. London, UK: EarthScan, United Nations Development Program.

UNEP (United Nations Environment Programme). 2002. Global environment outlook - 3. London, UK: UNEP

Vessuri H. 2003. Science, politics, and democratic participation in policy-making: a Latin American view. Technol Soc 25: 263-73.

World Bank. 2005. Mexico country brief. www.worldbank.org/mx. Viewed 30 March 2006. 